showed that optical activity and the existence of two optically active isomers, differing merely in the sign of their rotations, occurred only when an asymmetric carbon atom was present. A short period as Dozent in physics at the Utrecht State Veterinary School was followed by a move to Amsterdam, where at the age of twenty-six he became professor of chemistry, mineralogy and geology at the newly created University. In his classic "Etudes de dynamique chimique" (1884) he successfully applied the laws of thermodynamics to the problems of chemical equilibrium and affinity, and two years later he evolved his famous theory of solutions, which helped to develop the theory of electrolytic dissociation and modern electrochemistry. In 1896 he accepted a research professorship in chemistry at the Royal Prussian Academy of Sciences in Berlin. Among his many-sided investigations his study of oceanic salt deposits inaugurated a new era in experimental mineralogy. His numerous honours included the Nobel Prize for Chemistry (1901), the foreign membership of the Royal Society (1897) and the German order Pour le mérite. Van't Hoff was a simple, friendly person, the last years of whose life were clouded with illness, necessitating periods of rest in sanatoria. He died at Steglitz on March 1, 1911 .

Pharmaceutical Society : Research and other Awards

THE Pharmaceutical Society has awarded its research scholarship of $£ 300$ a year for two years to L. E. Coles, who will be engaged in the School of Pharmacy, University of London, in completing work on the synthetic analogues of the adrenal cortical hormones. Wellcome Pharmaceutical Research Fellowships, each of $£ 350$ a year, have been awarded to J. Thomas, for work in the Department of Pharmacy, University of Manchester, on the chemical synthesis of biological activity, particularly bactericidal action, of a new series of quaternary ammonium compounds, and to G. L. Willey, for research at the University of Leeds on the possibility of selectivity of action of nicotine-like stimulant compounds. The Society also made the following awards : Jacob Bell Memorial Scholarship ( $£ 150$ with $£ 5$ worth of books), to T. M. French, of Northampton; Manchester Pharmaceutical Association Scholarship (£45), to R. A. Alcock, of Ormskirk; and the Devon and Cornwall Exhibition in Pharmacy (£25), to A James, of Tiverton.

\section{Courtauld's Scientific and Educational Trust Fund: Awards}

TFE trustees of the Courtaulds' Scientific and Educational Trust Fund have announced the award for 1952 of the following postgraduate research scholarships in a branch of science related to the textile, plastics and allied industries, which are worth $£ 375$ (except where otherwise stated). and are tenable for one year at the institute shown: D. W. Bannister and P. T. Speakman, University of Oxford ; H. W. W. Brett, University of Adelaide; C. S. Chadwick, Manchester College of Technology ; F. S. Hill, University of Liverpool ; J. W. Ladbury, Imperial College of Science and Technology, London; D. C. Blackley (renewal of 1951 award), C. J. Pearce, B. D. Stead and C. N. Turton, University of Birmingham ; J. Russell (renewal of 1951 award), Bradford Technical College; J. Saunders (£93 15s., renewal of 1951 award for autumn term only), University of Bristol ; A. E. Somerfield (renewal of 1951 award),
Trinity College, Dublin. Postgraduate research scholarships in textile technology, worth $£ 300$ a year for two years, have been awarded as follows: $E$. Attle and S. L. Fitton, Manchester College of Technology; C. S. bruce, D. Hardisty, Miss P. Harris and $J$. A. Leathley, University of Leeds.

\section{Common Names of British Insect Pests}

IN 1944 the Conference of Advisory Entomologists and the Pests and Diseases Committee of the Association of Applied Eiologists set up a joint sub-committee to prepare a list of common names of the insect and related pests of garden plants, domestic animals, stored products and timber as they occur in Britain. The first part, dealing with slugs and snails, eelworms, beetles, hymenopterous insects and flies, was published in 1947. The second part, dealing with lice, thrips, plant bugs, aphids, and scale insects, Lepidoptera, fleas, mites and ticks, has recently appeared. Eoth parts consist of alphabetical lists of the accepted British common names (often with the American equivalents) and the corresponding scientific names; and alphabetical lists of the scientific names (under genera) and the recommended common name. These lists will be of great value to all applied entomologists in Great britain in enabling them to secure some degree of uniformity in the names of their pests. Not all the names will have equally ready acceptance by everyone. It is interesting to find the editor admitting quite frankly that "by the very nature of the International kules governing Zoological Nomenclature the scientific names must constantly be subject to revision". It is intended to publish revised lists from time to time. Copies of the list can be obtained from Miss Farbara M. Stokes, Entomology Department, Rothamsted Experimental Station, Harpenden, Herts (Part 1, 2s. ; Part 2, 3s.).

\section{Scientific Papers Published in the Middle East}

Lrst No. 6 (December 1950) of "Scientific Papers published in the Middle East", issued by the Unesco Middle East Science Co-operation Office, Cairo, covers papers published in Cyprus, Egypt, Iran, Iraq, Israel, Lebanon, Pakistan, Sudan, Syria and Turkey, and received by the Office between March 1 and November 1, 1950. Publications from Pakistan are included for the first time, and the issue includes more than thirteen hundred titles, arranged under the Universal Decimal Classification. There is also a list of periodicals included, arranged by country of origin, and a list of abbreviations used. Roughly two-fifths of the entries fall under the modical sciences, one fifth in engineering and various industries, and one fifth in agriculture, forestry or stockbreeding. An author index covering the first six lists published by the Office at Cairo (pp. 27) has also been issued. With regard to Arabic names, only the last (according to Egyptian usage) has been retained as surname, and, whenever possible, only one spelling has been selected in the transliteration of Arabic sounds.

\section{British Interplanetary Society}

THE annual report of the British Interplanetary Society for 1951 (pp. 18 ; from the Society, 157 Friary Road, London, S.E.15; 1951) shows a remarkable enthusiasm among its fellows and members, and also a keen public interest, judging from the number of lectures delivered during the 1950-51 session. Although the Society has been in existence for only six years, it appears that its expansion has been such that a full-time clerical 